\title{
A case report of T-box 1 mutation causing phenotypic features of chromosome 22q11.2 deletion syndrome
}

\author{
Raad A. Haddad", Gregory A. Clines and Jennifer A. Wyckoff
}

\begin{abstract}
Background: The heterozygous microdeletion of chromosome 22q11.2 results in a spectrum of disorders, including DiGeorge syndrome (DGS) and velocardiofacial syndrome (VCFS), with phenotypic features that can include the classic triad of congenital heart disease (CHD), thymic aplasia and hypoparathyroidism. Such microdeletions are usually detectable by fluorescence in situ hybridization (FISH).

Case presentation: We report a case of a twenty-three year-old female who presented with clinical features of chromosome 22q11.2 deletion syndrome including cardiac anomalies, hypoparathyroidism and dysmorphic facial features. FISH did not reveal a 22q11.2 microdeletion. Further genetic analysis showed T box-1 (TBX1) heterozygous mutation.

Conclusions: The TBX1 gene plays a significant role in the development of fourth pharyngeal arch structures. Mutations of TBX1, which is found at chromosome 22q11.21 can be responsible for the development of syndromes classically associated with chromosome 22q11.2 deletions. This case emphasizes that the TBX1 gene, among other genes, can be responsible for the developmental anomalies seen in these syndromes.
\end{abstract}

Keywords: 22q11.2 deletion, DiGeorge syndrome, Hypoparathyroidism, Hypocalcemia

\section{Background}

A wide spectrum of phenotypic features may present as a result of the deletion of chromosome 22q11.2. DiGeorge syndrome (DGS), velocardiofacial syndrome (VCFS), and various other syndromes have been described in association with the deletion involving human chromosome 22q11.2 [1]. The T-box 1 (TBX1) gene, located on chromosome 22q11.21, has a significant role in the differentiation and development of the third and fourth pharyngeal arches into the pharyngeal arch arteries, cardiac outflow tract, thymus, parathyroid glands, and craniofacial structures [2-4]. We report a case of a twenty-three year-old female who presented with phenotypic features of 22q11.2 deletion and was found to have heterozygous mutation of the TBX1 gene.

\footnotetext{
* Correspondence: haddraad@gmail.com

Division of Metabolism, Endocrinology, and Diabetes (MEND), Department of Internal Medicine, University of Michigan, 24 Frank Lloyd Wright, G-1500, Ann Arbor, MI 48106, USA
}

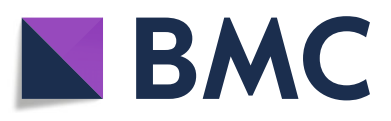

(c) The Author(s). 2019 Open Access This article is distributed under the terms of the Creative Commons Attribution 4.0 International License (http://creativecommons.org/licenses/by/4.0/), which permits unrestricted use, distribution, and reproduction in any medium, provided you give appropriate credit to the original author(s) and the source, provide a link to the Creative Commons license, and indicate if changes were made. The Creative Commons Public Domain Dedication waiver (http://creativecommons.org/publicdomain/zero/1.0/) applies to the data made available in this article, unless otherwise stated.
A twenty three year-old female presented to transition her care from pediatric to adult endocrinology. At the age of one year, she had presented to her local emergency department with seizures and was found to have serum calcium of $6.7 \mathrm{mg} / \mathrm{dL}$ (reference range 8.2-10.2 $\mathrm{mg} / \mathrm{dL}$ ). Her serum phosphorus level at that time was $7.8 \mathrm{mg} / \mathrm{dL}$ (reference range $2.3-4.7 \mathrm{mg} / \mathrm{dL}$ ) and magnesium of $2.3 \mathrm{mEq} / \mathrm{L}$ (reference range $1.5-2.5 \mathrm{mEq} / \mathrm{L}$ ). Testing performed at that time included an intact parathyroid hormone $(\mathrm{PTH}$ ) level of $15 \mathrm{pg} / \mathrm{mL}$ (reference range $10-65 \mathrm{pg} / \mathrm{mL}$ ), a 25 -hydroxyvitamin $\mathrm{D}$ level of 61 $\mathrm{ng} / \mathrm{mL}$ (reference range of $30-80 \mathrm{ng} / \mathrm{mL}$ ) and a 1,25 dihydroxyvitamin $\mathrm{D}$ level of $45 \mathrm{pg} / \mathrm{mL}$ (reference range $15-65 \mathrm{pg} / \mathrm{mL}$ ), consistent with hypocalcemia due to hypoparathyroidism. There was no history of candidiasis. By two years old, she was also diagnosed with multiple other conditions including hydrocephalus, atrial septal defect, bicuspid aortic valve, left kidney agenesis and thoracolumbar scoliosis. She was later diagnosed with learning disabilities including cognitive and attention 
deficits, no other psychiatric disorders were diagnosed. Her facial features are shown in Fig. 1 and are noticeable for dysmorphism of the nose, flattened philtrum, micrognathia and hypertelorism (not shown in the figure). She did not have palatal or teeth abnormalities. She underwent an immunological evaluation that was unremarkable. Her biochemical thyroid evaluation was also normal. Her hypoparathyroidism has been managed with calcitriol and calcium supplementation. Her corrected calcium levels were maintained in the range of 8.0-9.5 $\mathrm{mg} / \mathrm{dL}$. Her last 24-h urinary calcium was $163.5 \mathrm{mg} / \mathrm{dL}$. She has not developed nephrolithiasis, and renal ultrasound is significant only for an absent left kidney. Given the clinical features that were compatible with 22q11.2 deletion, she initially underwent FISH that did not reveal the targeted deletion. She then had bi-directional DNA sequencing that detected a heterozygous mutation (c.1055 C > T; p.Pro352Leu) resulting in a proline to leucine substitution at amino acid 352 in the TBX1 gene.

\section{Discussion and conclusions}

Chromosome 22q11.2 deletion syndrome accounts for the most common microdeletion disorder in humans with an estimated incidence of 1 in 4000-10,000 live births. $[5,6]$. The clinical features of this microdeletion were first described as a triad of congenital heart disease

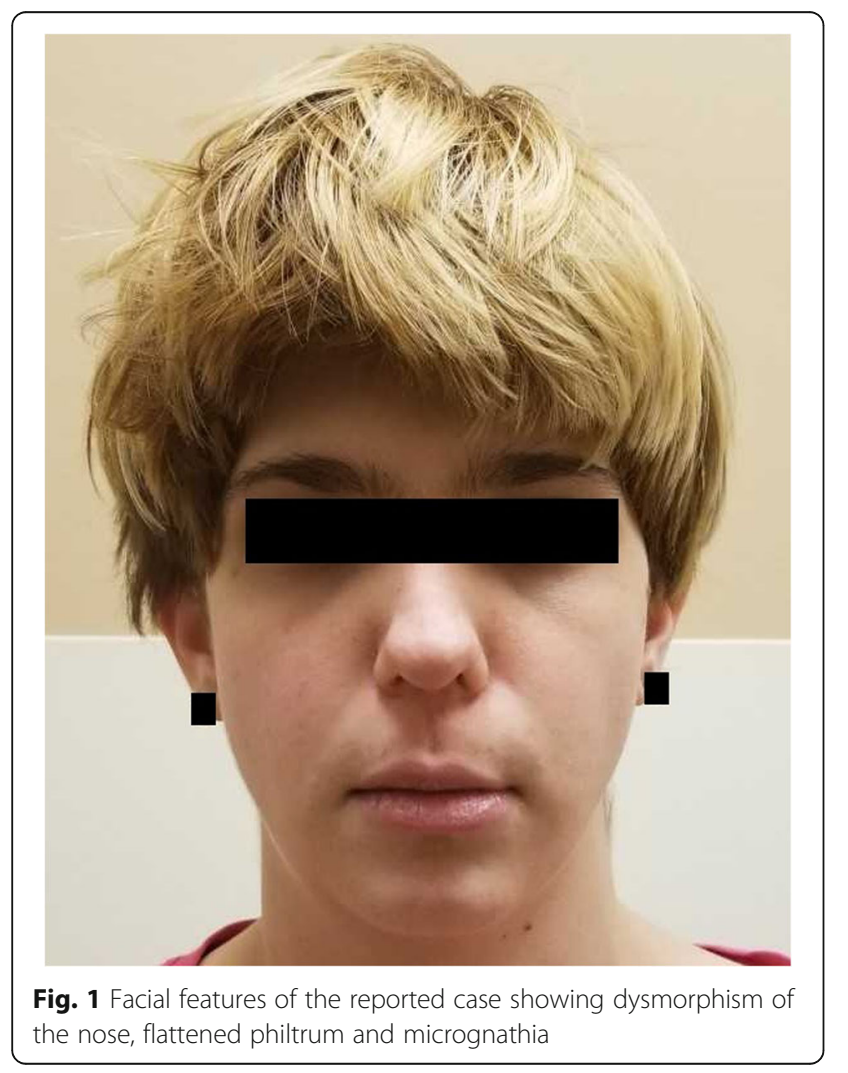

(CHD), thymic aplasia and hypoparathyroidism by Dr. Angelo DiGeorge in 1965. [7, 8]. Other conditions were subsequently described with overlapping phenotypic features including velocardiofacial syndrome (VCFS), conotruncal anomaly face syndrome, and Caylercardiofacial syndrome. [9-11]. It was later concluded that all of these syndromes share the same causative mutation with heterogeneous clinical presentations.

The majority of patients have a 3 Mega-base (Mb) heterozygous deletion of 22q11.2 segment that contains approximately 30 genes responsible for the early development of the pharyngeal arch derivatives, leading to compromised maturity of the craniofacial structures, the upper thorax, the thymus, the parathyroid glands, the heart, and the cardiac outflow tract [12-14]. A wide spectrum of clinical manifestations is observed including cardiac anomalies, immunodeficiency due to thymic aplasia, hypocalcemia due to hypoparathyroidism and dysmorphic facial features. Other findings include palatal, musculoskeletal, gastrointestinal, renal, behavioral, psychiatric (including anxiety and schizophrenia) and cognitive abnormalities (including learning disabilities, attention-deficit, and mental retardation) were also found to be related [15-17]. The clinical presentation of the patient reported here was compatible with the phenotypic features described. Her FISH analysis did not detect the expected deletion. Classically, FISH has been the routine diagnostic test to reveal such microdeletion. However, the reported sensitivity of this test was nearly $78 \%$ by Michaelovsky et al. [18]. Routine FISH technique uses a probe mapping to the LCR22A-LCR22B region, thus, deletions outside this region or deletions that are too small to detect can be left unrevealed $[8,19]$. In the case mentioned here, further genetic analysis revealed heterozygous mutation of the TBX1 gene (P352L variant). This variant has not been reported before in this syndrome, however, one missense mutation in a nearby residue (G350D) has been reported in association with cardiovascular defects [20].

The TBX1 gene has been extensively studied in mice; heterozygous TBX1 deleted mice were found to have aortic arch defects which represents one of the major characteristics of the 22q11.2 deletion syndrome [21]. Homozygous deletion of this gene in mice led to a wider spectrum of phenotypic characteristics including thymus and parathyroid abnormalities, cardiac outflow tract anomalies, and craniofacial defects $[22,23]$. In human studies, Yagi et al. performed mutational analysis in patients with 22q11.2 deletion syndrome features but without the chromosomal deletion; TBX1 heterozygous mutation was found responsible for major phenotypic features in this syndrome, predominantly, cardiac and cardiac outflow tract anomalies [2, 24, 25]. These findings confirmed that TBX1 gene haploinsufficiency 
plays a crucial role in the development of the 22q11.2 deletion syndromes.

In such cases, a multidisciplinary approach for management is required and depends on the age of presentation and the spectrum of consequences. Patients with this syndrome need individualized and complex medical care with vigilant recognition of the acute and long-term manifestations. From an endocrinology point of view, maintaining calcium homeostasis remains essential to prevent hypocalcaemia. The lack of PTH results in the under conversion of vitamin D (25-hydroxyvitamin D) to its active form (1, 25-dihydroxyvitamin D), and thus, low calcium absorption. Supplementation with calcium and active vitamin D (i.e. calcitriol) is the cornerstone of management $[26,27]$. These patients also lack the effect of the PTH on renal calcium reabsorption. It is therefore preferred to maintain serum calcium level in the low normal range to prevent hypercalciuria and the subsequent development of nephrolithiasis and renal failure [28]. Some patients may require thiazide diuretics to decrease urinary calcium excretion [29]. In patients who fail to maintain stable serum and urinary calcium on calcium and vitamin D supplementation, recombinant PTH can be given as a second line therapy. Recombinant human PTH (1-84), the native form of PTH, was approved by the U.S. food and drug administration (FDA) in 2015 for use in patients with chronic hypoparathyroidism. After double-blinded, randomized clinical trial reported a reduction of, or even independence from, supplemental calcium and calcitriol with stable serum and urinary calcium levels over 24 weeks [30]. Synthetic PTH (1-34), which is the active form of PTH and in fact FDA approved for use in osteoporosis, also showed favorable effect with improvement of hypercalciuria when compared to conventional therapy with calcitriol and calcium [31, 32].

Over the last two decades, studies have revealed the consequences of TBX1 haploinsufficiency in mice, mimicking the phenotypic features seen in 22q11.2 deletion syndrome. Human studies to date are limited giving the rarity of such mutations. The case reported here replicates the findings that were observed in previous human studies and underscores the fact that TBX1 gene mutation plays a key role in the development of this syndrome.

\section{Abbreviations}

CHD: Congenital heart disease; DGS: DiGeorge syndrome; FISH: Fluorescence in situ hybridization; Mb: Mega-base; PTH: Parathyroid hormone; TBX1: T box1; VCFS: Velocardiofacial syndrome

\section{Acknowledgements}

None

\section{Authors' contributions}

RAH, GAC and JAW participated in patient care. RAH wrote and edited the manuscript. All authors read and approved the final manuscript.
Funding

No funding was received to support this publication.

\section{Availability of data and materials}

The data used in this case report are available in the patient's medical recordand can be disclosed by the corresponding author on reasonable request.

Ethics approval and consent to participate

Not applicable.

\section{Consent for publication}

Written consent was obtained from the patient to publish the content of this case report.

\section{Competing interests}

The authors declare that they have no competing interests.

Received: 16 June 2019 Accepted: 30 July 2019

Published online: 13 August 2019

References

1. Scambler PJ. The 22q11 deletion syndromes. Hum Mol Genet. 2000; 9(16):2421-6.

2. Yagi H, Furutani $Y$, Hamada H, Sasaki T, Asakawa S, Minoshima S, Ichida F, Joo K, Kimura M, Imamura S, Kamatani N, Momma K, Takao A, Nakazawa M, Shimizu N, Matsuoka R. Role of TBX1 in human del22q11.2 syndrome. Lancet. 2003;362(9393):1366-73.

3. Lindsay EA, Vitelli F, Su H, Morishima M, Huynh T, Pramparo T, Jurecic V, Ogunrinu G, Sutherland HF, Scambler PJ, Bradley A, Baldini A. Tbx1 haploinsufficieny in the DiGeorge syndrome region causes aortic arch defects in mice. Nature. 2001;410(6824):97-101.

4. Arnold JS, Braunstein EM, Ohyama T, Groves AK, Adams JC, Brown MC, Morrow BE. Tissue-specific roles of Tbx1 in the development of the outer, middle and inner ear, defective in 22q11DS patients. Hum Mol Genet. 2006: 15(10):1629-39.

5. Goodship J, Cross I, LiLing J, Wren C. A population study of chromosome 22q11 deletions in infancy. Arch Dis Child. 1998;79(4):348-51.

6. Wilson DI, Burn J, Scambler P, Goodship J. DiGeorge syndrome: part of CATCH 22. J Med Genet. 1993;30(10):852-6.

7. DiGeorge A. Discussion on a new concept of the cellular immunology. J Pediatr. 1965;67:907-8.

8. McDonald-McGinn DM, Sullivan KE, Marino B, Philip N, Swillen A, Vorstman JA, Zackai EH, Emanuel BS, Vermeesch JR, Morrow BE, Scambler PJ, Bassett AS. 22q11.2 deletion syndrome. Nat Rev Dis Primers. 2015;1:15071. https:// doi.org/10.1038/nrdp.2015.71.

9. Driscoll DA, Salvin J, Sellinger B, Budarf ML, McDonald-McGinn DM, Zackai EH, Emanuel BS. Prevalence of 22q11 microdeletions in DiGeorge and velocardiofacial syndromes: implications for genetic counselling and prenatal diagnosis. J Med Genet. 1993;30(10):813-7.

10. Matsuoka R, Takao A, Kimura M, Imamura S, Kondo C, Joh-o K, Ikeda K, Nishibatake M, Ando M, Momma K. Confirmation that the conotruncal anomaly face syndrome is associated with a deletion within 22q11.2. Am J Med Genet. 1994;53(3):285-9.

11. Giannotti A, Digilio MC, Marino B, Mingarelli R, Dallapiccola B. Caylercardiofacial syndrome and del 22q11: part of the CATCH22 phenotype. Am J Med Genet. 1994;53(3):303-4.

12. Shaikh TH, Kurahashi H, Saitta SC, O'Hare AM, Hu P, Roe BA, Driscoll DA, McDonald-McGinn DM, Zackai EH, Budarf ML, Emanuel BS. Chromosome 22specific low copy repeats and the 22q11.2 deletion syndrome: genomic organization and deletion endpoint analysis. Hum Mol Genet. 2000;9(4):489-501.

13. D'Angelo CS, Jehee FS, Koiffmann CP. An inherited atypical 1 Mb 22q11.2 deletion within the DGSNCFS $3 \mathrm{Mb}$ region in a child with obesity and aggressive behavior. Am J Med Genet A. 2007;143A(16):1928-32.

14. Boorman JG, Varma S, Ogilvie CM. Velopharyngeal incompetence and chromosome 22q11 deletion. Lancet. 2001;357(9258):774.

15. Kobrynski LJ, Sullivan KE. Velocardiofacial syndrome, DiGeorge syndrome: the chromosome 22q11.2 deletion syndromes. Lancet. 2007;370(9596):1443-52.

16. Hacıhamdioğlu B, Hacıhamdioğlu D, Delil K. 22q11 deletion syndrome: current perspective. Appl Clin Genet. 2015;8:123-32. https://doi.org/1 $0.2147 /$ TACG.S82105. 
17. Arinami T. Analyses of the associations between the genes of $22 q 11$ deletion syndrome and schizophrenia. J Hum Genet. 2006;51(12):1037-45 Epub 2006 Sep 13.

18. Michaelovsky E, Frisch A, Carmel M, Patya M, Zarchi O, Green T, BaselVanagaite L, Weizman A, Gothelf D. Genotype-phenotype correlation in 22q11.2 deletion syndrome. BMC Med Genet. 2012;13:122. https://doi.org/1 $0.1186 / 1471-2350-13-122$

19. Shi H, Wang Z. Atypical microdeletion in $22 q 11$ deletion syndrome reveals new candidate causative genes: a case report and literature review. Medicine (Baltimore). 2018;97(8):e9936. https://doi.org/10.1097/MD. 0000000000009936

20. Stenson PD, Mort M, Ball EV, Howells K, Phillips AD, Thomas NS, Cooper DN. The human gene mutation database: 2008 update. Genome Med. 2009;1(1): 13. https://doi.org/10.1186/gm13.

21. Zweier C, Sticht H, Aydin-Yaylagül I, Campbell CE, Rauch A. Human TBX missense mutations cause gain of function resulting in the same phenotype as 22q11.2 deletions. Am J Hum Genet. 2007:80(3):510-7.

22. Jerome LA, Papaioannou VE. DiGeorge syndrome phenotype in mice mutant for the T-box gene, Tbx1. Nat Genet. 2001;27(3):286-91.

23. Gong W, Gottlieb S, Collins J, Blescia A, Dietz H, Goldmuntz E, McDonaldMcGinn DM, Zackai EH, Emanuel BS, Driscoll DA, Budarf ML. Mutation analysis of TBX1 in non-deleted patients with features of DGSNCFS or isolated cardiovascular defects. J Med Genet. 2001;38(12):E45.

24. Baldini A. Dissecting contiguous gene defects: TBX1. Curr Opin Genet Dev. 2005;15(3):279-84.

25. Ganji H, Salehi M, Sedghi M, Abdali H, Nouri N, Sadri L, Hosseinzadeh M, Vakili B, Lotfi M. Investigation of TBX1 gene deletion in Iranian children with 22q11.2 deletion syndrome: correlation with conotruncal heart defects. Heart Asia. 2013;5(1):200-2. https://doi.org/10.1136/heartasia-2013-010327 eCollection 2013.

26. Bilezikian JP, Brandi ML, Cusano NE, Mannstadt M, Rejnmark L, Rizzoli R, Rubin MR, Winer KK, Liberman UA, Potts JT Jr. Management of Hypoparathyroidism: present and future. J Clin Endocrinol Metab. 2016; 101(6):2313-24. https://doi.org/10.1210/jc.2015-3910.

27. Mortensen L, Hyldstrup L, Charles P. Effect of vitamin D treatment in hypoparathyroid patients: a study on calcium, phosphate and magnesium homeostasis. Eur J Endocrinol. 1997;136(1):52-60.

28. Gesek FA, Friedman PA. On the mechanism of parathyroid hormone stimulation of calcium uptake by mouse distal convoluted tubule cells. J Clin Invest. 1992;90(3):749-58.

29. Porter RH, Cox BG, Heaney D, Hostetter TH, Stinebaugh BJ, Suki WN. Treatment of hypoparathyroid patients with chlorthalidone. N Engl J Med. 1978;298(11):577-81.

30. Mannstadt M, Clarke BL, Vokes T, Brandi ML, Ranganath L, Fraser WD, Lakatos P, Bajnok L, Garceau R, Mosekilde L, Lagast H, Shoback D, Bilezikian JP. Efficacy and safety of recombinant human parathyroid hormone (1-84) in hypoparathyroidism (REPLACE): a double-blind, placebo-controlled, randomised, phase 3 study. Lancet Diabetes Endocrinol. 2013;1 (4):275-83. https://doi.org/10.1016/S2213-8587(13)70106-2.

31. Winer KK, Ko CW, Reynolds JC, Dowdy K, Keil M, Peterson D, Gerber LH, McGarvey C, Cutler GB Jr. Long-term treatment of hypoparathyroidism: a randomized controlled study comparing parathyroid hormone-(1-34) versus calcitriol and calcium. J Clin Endocrinol Metab. 2003;88(9):4214-20.

32. Winer KK, Sinaii N, Peterson D, Sainz B Jr, Cutler GB Jr. Effects of once versus twice-daily parathyroid hormone 1-34 therapy in children with hypoparathyroidism. J Clin Endocrinol Metab. 2008;93(9):3389-95. https:// doi.org/10.1210/jc.2007-2552.

\section{Publisher's Note}

Springer Nature remains neutral with regard to jurisdictional claims in published maps and institutional affiliations.

Ready to submit your research? Choose BMC and benefit from:

- fast, convenient online submission

- thorough peer review by experienced researchers in your field

- rapid publication on acceptance

- support for research data, including large and complex data types

- gold Open Access which fosters wider collaboration and increased citations

- maximum visibility for your research: over $100 \mathrm{M}$ website views per year

At BMC, research is always in progress.

Learn more biomedcentral.com/submissions 